Pablo J. López-González

\title{
A new gorgonian genus from deep-sea Antarctic waters (Octocorallia, Alcyonacea, Plexauridae)
}

Received: 11 August 2004/ Revised: 19 June 2005/ Accepted: 4 July 2005 / Published online: 25 August 2005

(C) Springer-Verlag and AWI 2005

\begin{abstract}
Mesogligorgia scotiae gen. nov., sp. nov. is described and illustrated from a colony collected in the Scotia Sea, 2,201-2,213 $\mathrm{m}$ in depth, on the ANDEEP-I cruise. The new taxon is placed in the family Plexauridae because of: 1) the presence of a horny axis with a crosschambered central core and numerous loculi, 2) retractile polyps in calyces with distinct spicular components, and 3) armed polyps with large sclerites with a poorlydeveloped collaret and eight well-developed points. The irregularly distributed sclerites running along the axis, into a thick mesogloeal coenenchyme, and the elongated spindles with irregular ends are the most distinctive characters of the newly proposed genus.
\end{abstract}

Keywords Cnidaria Octocorallia $\cdot$ Alcyonacea Plexauridae $\cdot$ Antarctica $\cdot$ Mesogligorgia

\section{Introduction}

Among the gorgonian families, Plexauridae is one of the richest in genera and species (Bayer 1956, 1981). This family is especially well represented in temperate and tropical waters (e.g. Bayer 1961; Grasshoff 1992, 1999, 2000; Fabricius and Alderslade 2001), and also in deep waters (e.g. Wright and Studer 1889; Bayer 1956; Grasshoff 1977, 1986). Although plexaurids are present in moderately high latitudes $\left(58^{\circ}-68^{\circ}\right)$ of the Northern Hemisphere of the Atlantic and Pacific (e.g. Kramp 1939; Madsen 1944; Grasshoff 1977; Sánchez and Cairns 2004; Sanmartín and P.J. López-González in prep), they are scarce in the high latitudes of the Southern Hemi-

Communicated by R.M. Kristensen

P. J. López-González

Biodiversidad y Ecología de Invertebrados Marinos,

Departamento de Fisiología y Zoología,

Facultad de Biología, Universidad de Sevilla,

Reina Mercedes, 6, 41012 Sevilla, Spain

E-mail: pjlopez@us.es sphere, which are dominated by the families Primnoidae and Isididae (e.g. Bayer 1996a, b, 1998; Alderslade 1998; López-González and Gili 2002).

On some recent Antarctic cruises, an extensive collection of octocorals has been made in the Weddell Sea, off the Antarctic Peninsula, and Scotia Sea. Among them, two ANDEEP cruises (Antarctic benthic deep-sea biodiversity; ANDEEP-I and ANDEEP-II, both in the austral summer 2002) were carried out on board the R/V Polarstern in the Scotia Sea to investigate the colonization history and recent community patterns of Antarctic benthic fauna. During the ANDEEP-I cruise an undescribed gorgonian, here placed in the family Plexauridae, was collected. The aim of this paper is the description of a new genus and species based on that material.

\section{Methods}

The material was collected in the Scotia Sea (Fig. 1) during the ANDEEP-I cruise. The octocorals were sorted, labelled and fixed on board. The holotype colony studied was fixed in buffered formaldehyde $(4 \%$ in sea water) and later preserved in $70 \%$ ethanol. Fragments from different parts of the colony were prepared for SEM study following the usual methodology (e.g. Bayer and Stefani 1988; Alderslade 1998), and permanent mounts were made for light microscopy. Colony and sclerite terminology follows Bayer et al. (1983). The specimen studied has been deposited in the Zoologisches Institut und Zoologisches Museum in Hamburg (ZI$\mathrm{ZMH})$.

\section{Results}

Subclass Octocorallia Order Alcyonacea

Suborder Holaxonia

Family Plexauridae Gray, 1859 


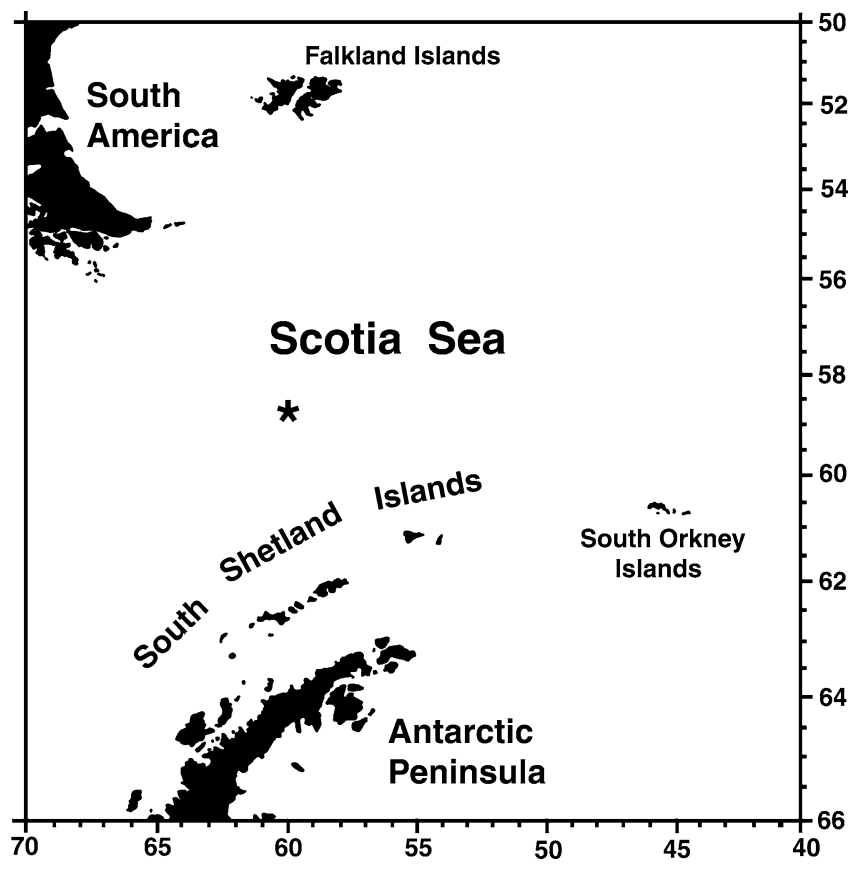

Fig. 1 Type locality of Mesogligorgia scotiae gen. nov., sp. nov. (asterisk)
Mesogligorgia gen. nov.

\section{Diagnosis}

Plexauridae with unbranched (possibly scarcely branched) colonies; holdfast well developed, cone shaped, not calcified. Coenenchyme remarkably thick with abundant mesogloea, in which sclerites are embedded forming distinct groups. Polyps scattered on all sides of the stem; polyps completely retractile in calyces embedded in the coenechymal mesoglea, only distinct as low dome-shaped verrucae with eight equally developed mesogloeal lobes. Sclerites elongated spindles with irregular edges; calicular sclerites indistinctly converging in eight points; anthocodial armature symmetrical, forming a poorly distinct collaret and eight well-developed points; flattened sclerites are present on the main axis of tentacles, and minute bodies on pinnules.

\section{Etymology}

The generic name combines Mesogli- in reference to the distinct abundance of mesogloea in the thick coenenchyme, and-gorgia, a common suffix in gorgonian generic names. Gender: feminine.
Fig. 2 Mesogligorgia scotiae gen. nov., sp. nov. Holotype ZIZMH (C 11689): a, whole colony, showing the conical holdfast, the irregular placement of polyps and the irregular diameter of the coenenchyme bearing polyps; b distal end; $\mathbf{c}$ a portion of the colony, showing the low calyces, and, due to transparency of the mesogloea, the eight points of the anthocodia and coenenchymal sclerites $(\cos )$; d limit between the basal coenenchyme without polyps and the upper part of the colony with polyps, showing the strong difference in diameter and the axis which is naked basally (ax). Scale bars: a $12 \mathrm{~mm}$; b-d, $4 \mathrm{~mm}$
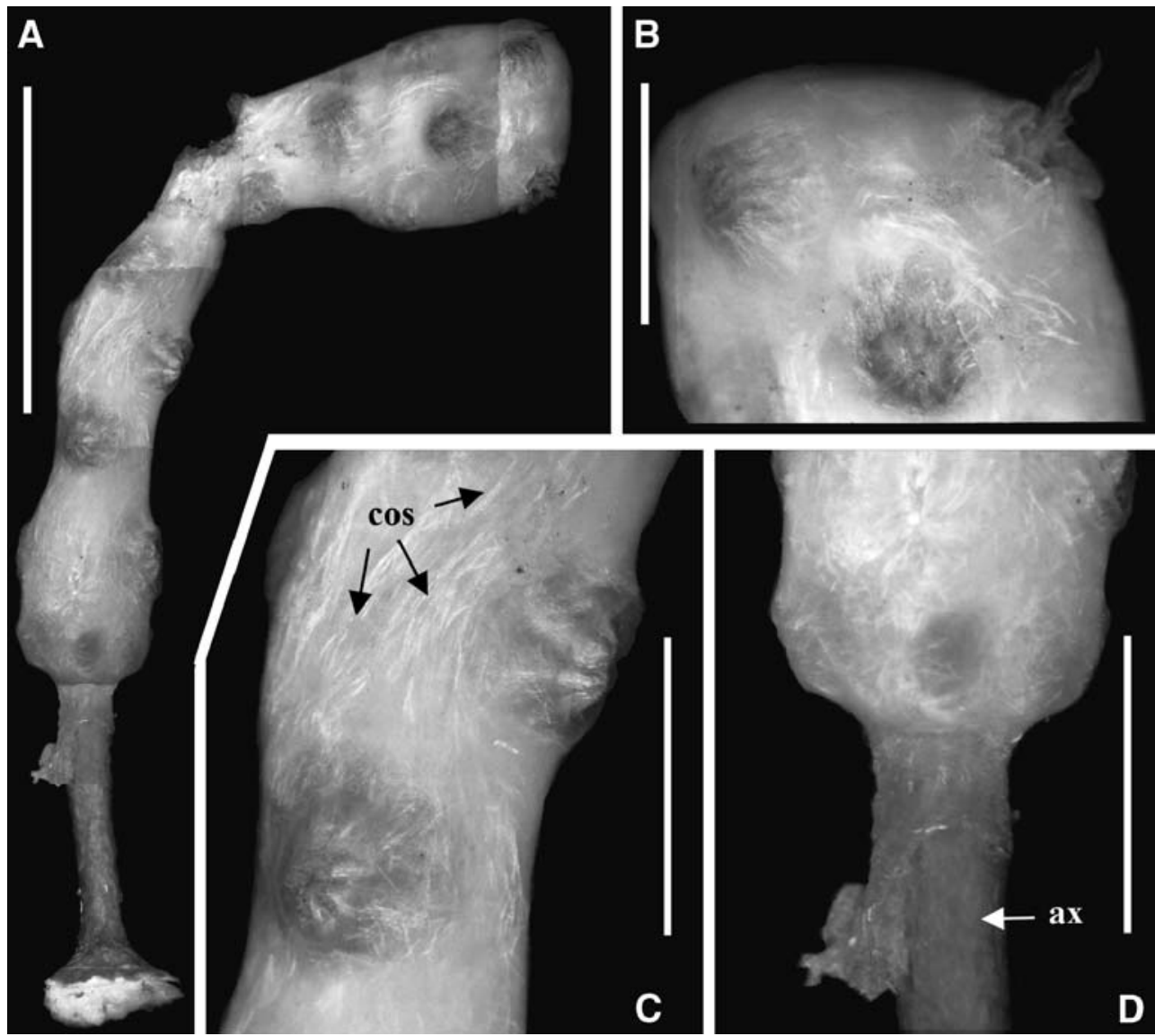
Type species

Mesogligorgia scotiae sp. nov. here designated.

Mesogligorgia scotiae sp. nov. (Figs. 2-5)

\section{Type material}

Holotype: ZIZMH (C 11689), one whole colony, ANDEEP-I cruise, Polarstern ANT XIX/3, stn. 41-4, Scotia Sea, 59²3.48'S 60³.54'W, 2,201-2,213 m, Agassiz trawl, 27 Jan 2002.

\section{Description}

The holotype is a complete colony with holdfast, about 40-mm high, and unbranched (Fig. 2a). The diameter is irregular along the main stem, about $3.7-8.0 \mathrm{~mm}$, with a claviform distal end. The coenenchyme of the polypbearing distal part, which has abundant translucent mesogloea, can be remarkably thick $(0.3-2.5 \mathrm{~mm})$ with respect to the basal part (Fig. 2d). Horny axis, $1.65 \mathrm{~mm}$ in diameter at basal level, has a cross-chambered central core and numerous loculi (Fig. 4a, b). The holdfast is cone-shaped, not calcified (Fig. 2a).

The polyps are irregularly placed around the stem (Fig. 2b, c). The anthocodiae are completely retractile into the calyces. Calyces are low, embedded in the coenechymal mesoglea, only distinct as low dome-shaped verrucae with eight equal mesogloeal lobes, $1.8-2.5 \mathrm{~mm}$ in diameter and 0.26-0.43-mm tall (Figs. 2, 3).

All sclerites in the colony are elongated spindles with irregular edges, sometimes with bi- or trifurcated ends (Fig. 5). The coenenchymal sclerites (Fig. 5a) are sparsely and irregularly distributed (Figs. 2b-d, 3, 4a, b), $0.47-1.10 \mathrm{~mm}$ in length, embedded in the abundant mesogloea. The coenenchymal sclerites can be observed in situ, sometimes running more or less longitudinally along the main axis. The calicular sclerites (Fig. 5b), $0.55-0.79 \mathrm{~mm}$ in length, are indistinctly converging in eight points, forming a deep palisade embedded into the coenenchymal mesogloea, and can be observed due to the transparency of the coenenchyme (Figs. 3, 4a, b). The anthocodial armature is symmetrical, forming an indistinct collaret and eight well-developed points with numerous lines of sclerites (Fig. 4c), 0.39-0.55 mm in length (Fig. 5c). The tentacular sclerites are flattened and slightly curved (Fig. 5d), obliquely placed on both sides of the main axis (Fig. 4d), 0.26-0.39 $\mathrm{mm}$ in length. Minute calcareous bodies $(<0.012 \mathrm{~mm})$ are present on pinnules (Fig. 4e).

The holotype colony was male, with developing spermatic cysts up to $0.22 \mathrm{~mm}$.

\section{Colour}

The living holotype was violet, whitish to dirty grey in the preserved state. The sclerites are colourless.
Fig. 3 Mesogligorgia scotiae gen. nov., sp. nov. Holotype ZIZMH (C 11689): $\mathbf{a}$ and b, retracted polyps in vertical view, showing the palisade of calicular sclerites (cs) in indistinctly converging groups and calicular aperture with mesogloeal lobes, and - due to transparency of the

mesogloea-cos; $\mathbf{c}-\mathbf{e}$, retracted polyps in lateral view, showing the indistinct converging groups of calicular sclerites in $\mathbf{e}$, and the eight points sclerites $(p s)$ and calicular border $(c b)$ in $\mathbf{d}$ and e. Scale bars: a-e, $2 \mathrm{~mm}$
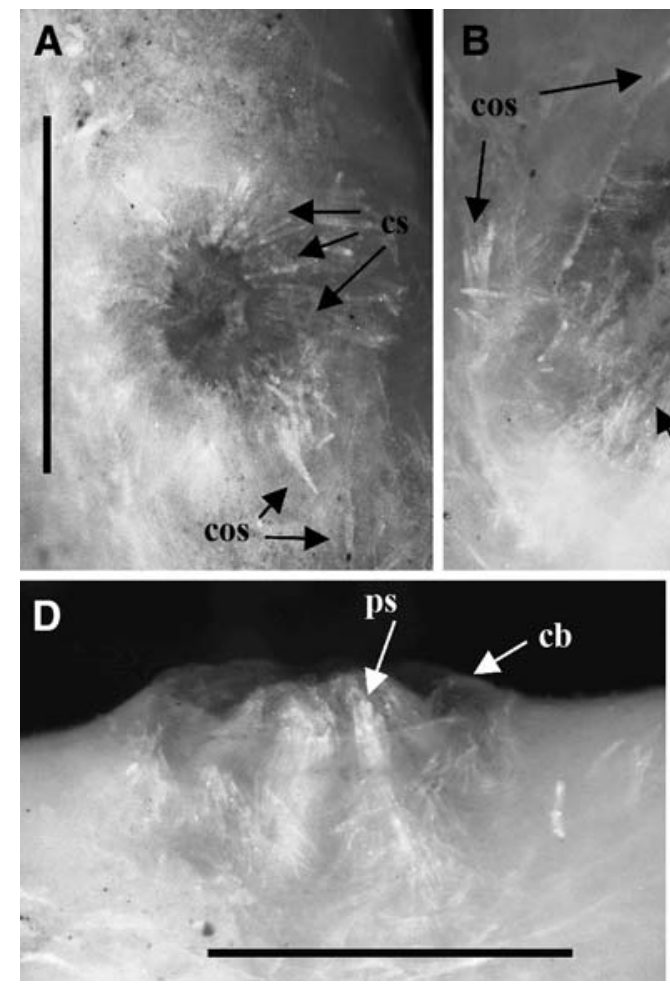
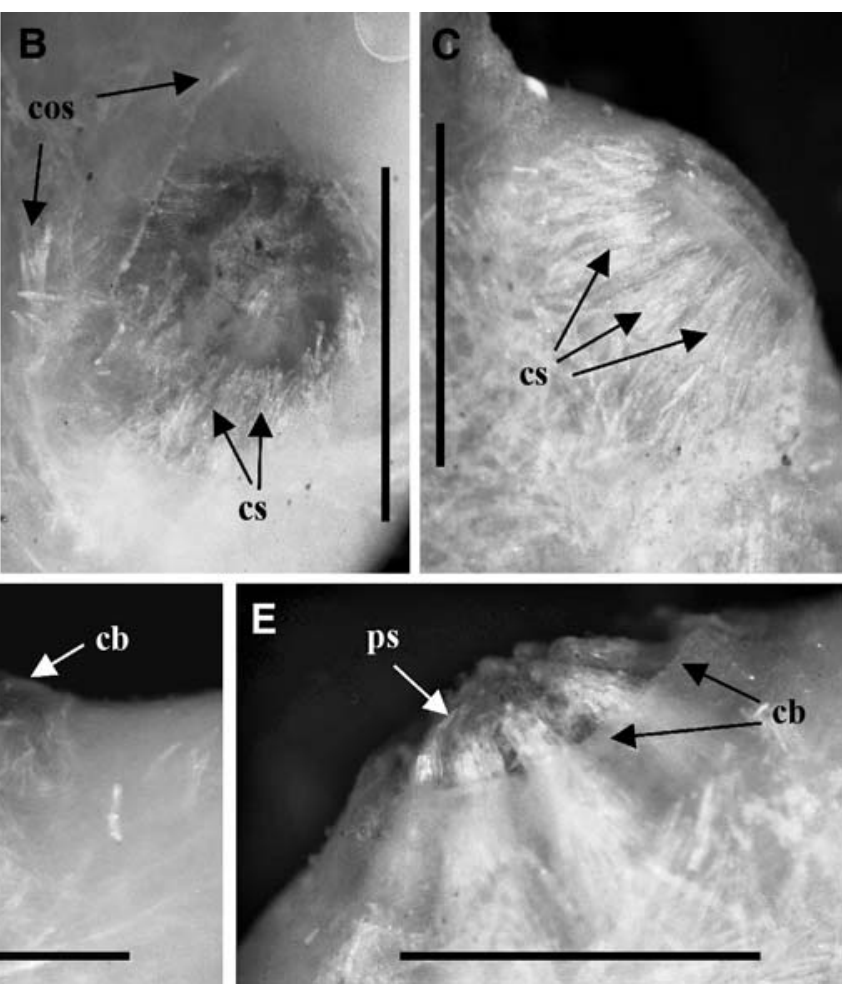


\section{Etymology}

The specific name scotiae refers to the geographic area where the new species was found.

\section{Geographical and bathymetric distribution}

At present, Mesogligorgia scotiae is known only from the Scotia Sea, depth 2,201-2,213 m.

\section{Discussion}

The presence of a horny axis with a cross-chambered central core and numerous loculi, retractile polyps armed with large sclerites in collaret and points, and calyces with distinct spicular components clearly support the inclusion of Mesogligorgia in the family Plexauridae.

As stated above, Plexauridae is one of the richest families in genera and species, although, the new taxon Mesogligorgia shows a set of characters (outlined above) not previously found in the family. For the following comparisons, additional information of the different plexaurid genera can be found in Germanos (1896), Wright and Studer (1889), Kükenthal (1919, 1924), Bayer (1956, 1961, 1981), Carpine and Grasshoff (1975), Grasshoff (1977, 1986, 1992, 1999, 2000), Williams (1992), Fabricius and Alderslade (2001) and Sánchez and Cairns (2004).

Mesogligorgia clearly differs from genera such as Pseudopleaxura Wright and Studer, 1889; Eunicea (s.1.)
Lamouroux, 1816; Plexaura Lamouroux, 1812; Muriceopsis Aurivillus, 1931 and Psammogorgia Verrill, 1868 by the absence of club-shaped sclerites; and from Bebryce Philippi, 1841 and Plexaurella Valenciennes, 1855 by the absence of sclerites as stellate plates or stellate forms with four or more rays.

A number of plexaurid genera show characteristic calicular sclerites as thorn-scales or thorn-spindles, such as Villogorgia (s.1.) Duchassaing and Michelotti, 1860; Acanthacis Deichmann, 1936; Astromuricea Germanos, 1895; Dentomuricea Grasshoff, 1977; Paramuricea Kölliker, 1865; Placogorgia Kükenthal, 1919; Lepidomuricea Kükenthal, 1919; Muriceides Studer, 1887; Echinogorgia Kölliker, 1865; Echinomuricea Verrill, 1869; Trimuricea Gordon, 1926 or Spinimuricea Grasshoff, 1992; however, these sclerites are absent in Mesogligorgia.

The presence of capstans clearly distinguish Swiftia Duchassaing and Michelotti, 1864; Heterogorgia Verrill, 1868; Anthoplexaura Kükenthal, 1908 and Alaskagorgia Sánchez and Cairns, 2004 from Mesogligorgia. Lytreia Bayer, 1981 is characterized by a superficial layer of small coenenchymal tuberculate spheres and doubleheaded sclerites, and Menacella Gary, 1870 by spindles with crenulated or foliate tubercles, which are absent in Mesogligorgia.

Menella Gray, 1870 and Paraplexaura Kükenthal, 1909 show surface sclerites with vertically placed leaves, or sculptured with blunt humps, respectively, completely different from the deep layer of elongated spindles present in the new taxon here described.
Fig. 4 Mesogligorgia scotiae gen. nov., sp. nov. Holotype ZIZMH (C 11689): a

longitudinal section of the distal end, showing the retracted polyps, the cross-chambered $a x$, some spermatic cysts in one of the sectioned polyps, and the thick coenenchyme; $\mathbf{b}$ detail of a showing a sectioned polyp, ax, deep layer of coenenchymal sclerites (coe), thick layer of mesogloea (me); $\mathbf{c}$ detail of the poorly distinct crown and welldeveloped eight point of a polyp after dissolution of the soft tissue by the use of a solution of sodium hypochlorite; $\mathbf{c}$ lateral view of a tentacle showing the oblique placement of tentacular sclerites, the soft tissue on the right are the pinnules; e a tentacular sclerite (out of focus) surrounded by several minute bodies $(<0.012 \mathrm{~mm}$, two of them arrowed) which are in the pinnules. Scale bars: a $4 \mathrm{~mm}$; b $2 \mathrm{~mm}$; c $1 \mathrm{~mm}$; d $0.5 \mathrm{~mm}$, e $0.1 \mathrm{~mm}$

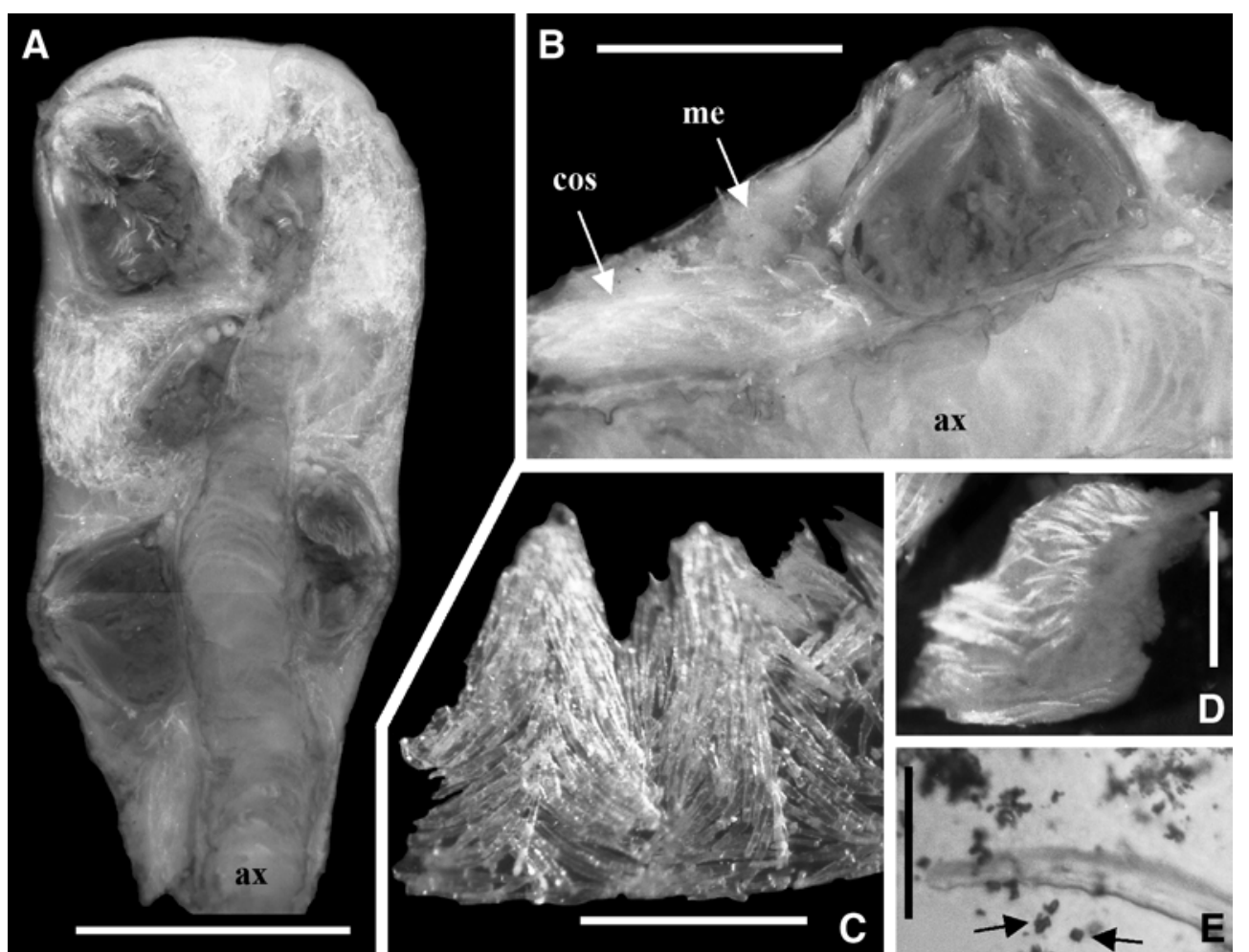


Fig. 5 Mesogligorgia scotiae gen. nov., sp. nov. Holotype ZIZMH (C 11689): a sclerites from the coenemchyme; $\mathbf{b}$ sclerites from the calyces; c sclerites from the crown and points; $\mathbf{d}$ sclerites from the axis of the tentacles, the two first sclerites are in lateral view. Scale bars: $0.3 \mathrm{~mm}$

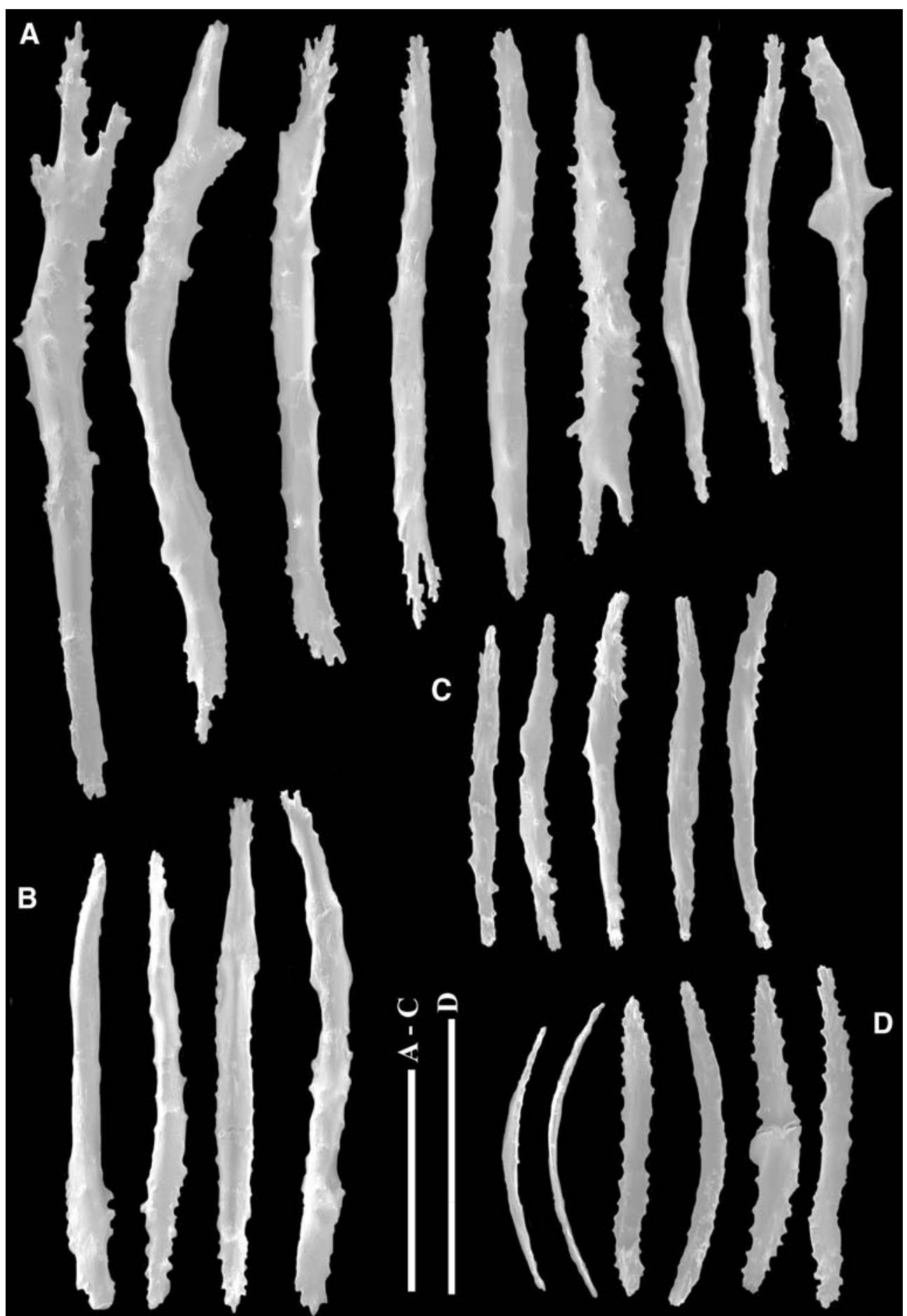

Hypnogorgia Duchassaing and Michelotti, 1864 and Mesogligorgia differ in the asymmetrical anthocodial armature of the former genus. The cylindrical or tubular calyces of Anthomuricea Studer, 1887 and Muricea (s.1.) Lamouroux, 1812 are quite different from the low mesogloeal calyces of Mesogligorgia. The surface sclerites in other genera are discoidal with lobate edges like in Discogorgia Kükenthal, 1919; or tuberculate to small prickled spindles like in Astro- gorgia Verrill, 1868 or Elasmogorgia Wright and Studer, 1889; which are quite different from those present in Mesogligorgia.

The typical two-lobed calyces of Calicogorgia Thomson and Henderson, 1906 and Caliacis Deichmann, 1936 can be used as a distinguishing character (among others) from Mesogligorgia in which the calicular apertures have eight equally developed mesogloeal lobes. Although the calyces of Euplexaura Verrill, 1869 
are low and inconspicuous, the sclerites are different from the sclerites of Mesogligorgia.

Three plexaurid genera have flattened spindles, Thesea Duchassaing and Michelotti, 1864; Scleracis Kükenthal, 1919 and Paracis Kükenthal 1919. However, in these genera coenenchymal sclerites are thick large plates or flattened spindles tightly fitted as in a mosaic, and there are clear differences in size and shape between coenenchymal and calicular sclerites. In Mesogligorgia all sclerites (except for the minute bodies found in the pinnules) are similar in shape, only varying in size range in the different parts of the colony. Coenenchymal sclerites are not arranged in a mosaic, running more or less longitudinally in different planes, embedded in the thick coenenchyme with abundant mesogloea.

Acknowledgements The author acknowledges the valuable assistance of the officers and crew of the R/V Polarstern, and many colleagues on board during the ANDEEP cruises. I take this opportunity to extend my thanks to the cruise leader and steering committee of both cruises (ANDEEP-I and ANDEEP-II), especially to Dieter Fütterer and Angelika Brandt, who kindly facilitated the work on board, and for the opportunity to collaborate in this Antarctic programme. The author thanks Mercedes Conradi for her valuable assistance during ANDEEP-I cruise, and Asunción Fernández (Scanning microscope services of the University of Seville) for her helpful assistance. Support for this work was provided by the MCT projects REN2001-4269-E/ANT and REN2001-4929E/ANT. The author is also thankful for comments and suggestions given by two anonymous referees. This is ANDEEP publication $n^{\circ}$ 48

\section{References}

Alderslade P (1998) Revisionary systematics in the gorgonian family Isididae, with description of numerous new taxa (Coelenterata, Octocorallia). Rec W Aust Mus Suppl 55:1-359

Bayer FM (1956) Octocorallia. In: Moore RC (ed) Treatise on Invertebrate Paleontology, Part F Coelenterata. University of Kansas Press, Lawrence, KS, pp F166-F230

Bayer FM (1961) The shallow-water Octocorallia of the West Indian region. A manual for marine biologists. Studies on the Fauna of Curaçao and other Caribbean Islands 12:1-373, pls. $1-27$

Bayer FM (1981) Key to the genera of Octocorallia exclusive of Pennatulacea (Coelenterata: Anthozoa), with diagnoses of new taxa. Proc Biol Soc Wash 94(3):901-947

Bayer FM (1996a) The Antarctic genus Callozostron and its relationship to Primnoella (Octocorallia: Gorgonacea: Primnoidae). Proc Biol Soc Wash 109(1):150-203
Bayer FM (1996b) New primnoid gorgonians (Coelenterata: Octocorallia) from Antarctic waters. Bull Mar Sci 58(2):511-530

Bayer FM (1998) A review of the circumaustral gorgonacean genus Fannyella Gray, 1870 with description of five new species (Coelenterata: Octocorallia: Primnoidae). Senckenberg biol 77(2):161-204

Bayer FM, Stefani J (1988) Primnoidae (Gorgonacea) de NouvelleCalédonie. Bull Mus natn Hist nat Paris (4) 10(A) 3:449-476

Bayer FM, Grasshoff M, Verseveldt J (1983) Illustrated trilingual glossary of morphological and anatomical terms applied to Octocorallia. E.J. Brill/Dr. W. Backhuys, Leiden, pp 1-75

Carpine C, Grasshoff M (1975) Les gorgonaires de la Méditerranée. Bull Inst océanogr. Monaco 71(1430):1-140

Fabricius K, Alderslade P (2001) Soft corals and sea fans. A comprehensive guide to the tropical shallow water genera of the central-west Pacific, the Indian Ocean and the Red Sea. Australian Institute of Marine Science, Townsville, Queensland, pp i-viii + 1-264

Germanos NK (1896) Gorgonaceen von Ternate. In: Kukenthal W (ed) Ergebnisse einer zoologischen Forschungsreise in den Molukken und Borneo, im Auftrage der Senckenbergischen naturforschenden Gesellschaft ausgefuhrt von Dr. Willy $\mathrm{Ku}-$ kenthal, Teil 2, Band 1. Abhandl Senckenb naturf Gesellsch 23 (1):145-187, 9-12

Grasshoff M (1977) Die Gorgonarien des ostlichen Nordatlantik und des Mittelmeeres. III. Die Familie Paramuriceidae (Cnidaria, Anthozoa). "Meteor" Forsch-Ergebnisse D27:5-76

Grasshoff M (1986) Die Gorgonaria der Expeditionen von "Travailleur" 1880-1882 und "Talisman" 1883 (Cnidaria: Anthozoa). Bull Mus natn Hist nat Paris (4)8(A)1:9-38

Grasshoff M (1992) Die Flachwasser-Gorgonarien von Europa und Westafrika (Cnidaria, Anthozoa). Cour Forsch-Inst Senckenberg 149:1-135

Grasshoff M (1999) The shallow water gorgonians of New Caledonia and adjacent islands (Coelenterata, Octocorallia). Senckenb Biol 78(1/2):1-121

Grasshoff M (2000) The gorgonians of the Sinai coast and the Strait of Gubal, Red Sea (Coelenterata, Octocorallia). Cour Forsch-Inst Senckenberg 224:1-125

Kramp PL (1939) Octocorallia. The Zoology of Iceland 2(7):1-13

Kükenthal W (1919) Gorgonaria. Wissensch Ergebn deutschen Tiefsee-Exped "Valdivia" 13 (2):1-946, 30-89

Kükenthal W (1924) Gorgonaria. Das Tierreich, pp 1-478

López-González PJ, Gili J-M (2002) A new primnoid genus (Anthozoa: Octocorallia) from the Southern Ocean. Sci Mar 66(4):383-397

Madsen FJ (1944) Octocorallia. Dan Ingolf-Exped 5(13):1-65

Sánchez JA, Cairns SD (2004) An unusual new gorgonian coral (Anthozoa: Octocorallia) from the Aleutian Islands, Alaska Zool Med Leiden 78(15):265-274

Williams GC (1992) The Alcyonacea of Southern Africa. Gorgonian Octocorals (Coelenterata, Anthozoa). Ann S Afr Mus 101(8):181-296

Wright EP, Studer T (1889) Report on the Alcyonaria collected by H.M.S. Challenger during the years 1873-1876. Rept Sci Res Challenger, Zool. 31:i-lxxvii $+1-314$ 